\title{
The Wage EXPECTATIONS Of EUROPEAN College Students
}

\author{
Giorgio Brunello \\ (Padova, CESifo, FEEM and IZA) \\ Claudio Lucifora \\ (Università Cattolica, Milan)
}

Rudolf Winter-Ebmer

(Linz, CEPR, IZA and WIFO)*

Working Paper No. 0108

March 28. 2001

Johannes Kepler University of Linz Department of Economics

Altenbergerstrasse 69 A-4040 Linz - Auhof, Austria www.economics.uni-linz.ac.at

$\left.{ }^{*}\right)$ corresponding author: r.winterebmer@jk.uni-linz.ac.at phone +43 (0)70 2468 -8236, -8238 (fax) 


\begin{abstract}
$\underline{\text { Abstract }}$
Expected earnings and expected returns to education are seen by labor economists as a major determinant of educational attainment. In spite of this, the empirical knowledge about expectations and their formation is scarce. In this paper we report the results of the first systematic study of the wage expectations of European college students. Our data are based on the replies to the same questionnaire by more than 6000 college students all over Europe. We study the determinants of wage expectations and expected employment probabilities, the variability of these expectations within a field of study and their variation across universities and fields. We also examine the trade-off between expected starting wages and wage growth. In the final section of the paper, we contrast expected returns to education with actual returns estimated from country-specific micro-data. In line with U.S. studies we find that students overestimate returns to education.
\end{abstract}

JEL: J30

Keywords: Returns to education, expectations formation, information processing.

We are grateful to Giovanni Bono, Josef Fersterer, Martin Maurhart and Natalia Pakhomova for excellent research assistance; to Mahmood Arai, Rita Asplund, Johann Bacher, Christoph Badelt, René Böheim, Josef Brüderl, Wolfgang Buchholz, Michael Burda, Kevin Denny, Bernd Fitzenberger, Knut Gerlach, Hermann Karcher, Pedro Pereira, Ali Skalli, Panos Tsakloglou, Volker Ulrich, Peter Welzel, Niels Westergard-Nielsen, Stefan Wolter, Robert Wright and Josef Zweimüller for help in administrating the survey in the different countries; to Julian Betts, Enrico Rettore and the audience at the New Orleans Meeting of the American Economic Association, January 2001, for comments. This research was supported by the European Commission under the TSER program PL980182 for the PuRE project. The usual disclaimer applies. 


\section{Introduction}

Expected earnings and expected returns to education are seen by labor economists as a major determinant of educational attainment and occupational choice and as a key factor in the decisions concerning labor mobility, training and re-training and the like. In most cases economists assume that individuals have perfect knowledge of future wages and wages in different contingencies - or that they have at least accurate point estimates of these key variables. This may not be true. Apart from being a serious blow to theories of human capital investment, highly practical consequences for college enrolment might also occur. In particular, several questions need to be answered: are expectations of students correct on average, and how big is the variability of forecasts? How are

expectations formed ${ }^{\square}$, and how effective and helpful are different ways of collecting the relevant information?

Unfortunately not many studies exist that consider these questions. On the one hand, economists have traditionally been very slow in accepting subjective information and very reluctant to ask people about their expectations. On the other hand, most available studies refer to the expectations of students in the U.S., where personal income and wage information is much more openly discussed than in most European countries.

The major contribution of this paper is its European focus. We use a unified scheme across 10 European countries to look at the wage expectations of European students, at their assessment of the returns to college education and at their determinants. Other studies have looked at wage expectations in the U.S., and the papers by Betts [1996] and Dominitz and Manski [1996] are closest in spirit to our research. Betts [1996] asks a sample of San Diego undergraduates about their views on earnings at the national level for several types of workers - some with and some without a college degree, and goes on to compare these expectations with actual earnings. Dominitz and Manski [1996] are interested in an assessment of individual wage prospects, not in expectations or knowledge of national averages. They ask not only for a point estimate, but also for a probability distribution of the expected salary.

Our approach takes elements from both papers. We are interested in the expectations of personal wage prospects under different contingencies, because students might be better able to forecast wages for themselves than for a "typical graduate". We refrain, however, from the elicitation of a whole probability distribution of future wage prospects, because it would be too

\footnotetext{
${ }^{1}$ See Manski [1993] for a discussion of expectations formation.
} 
difficult in a cross-country scale, especially for counter-factual questions such as the wages of highschool graduates.

It is difficult to find studies that compare the expectations of high-school and college wages with actual wages. Carvajal et al. [2000] use a questionnaire similar to ours to ask college seniors and recent graduates about starting wages. Unfortunately, they have only a relatively small sample from Miami. Webbink and Hartog [1999] use a longitudinal sample of Dutch students who had been previously interviewed about their future wage expectations to ask them about their starting wages. Remarkably, both the existing U.S. studies, which compare directly expectations with actual wages (Betts [1996] and Carvajal et al. [2000]) and the Dutch study (Webbink and Hartog [1999]) find expectations that are on average relatively close to realized wages.

Our approach is to ask college students in different countries about wages in different contingencies. In Section 2 we describe the questionnaire and the associated data set. Section 3 is devoted to the analysis of students' beliefs about college and high school wages. In Section 4, we try to relate the country and college specific differences in these beliefs to differences in school design and labor market institutions. Next (Section 5), we look at the trade off between expected wages and expected wage growth. Section 6 is devoted to studying the dispersion of individual beliefs across colleges and fields of study. Finally, we compare these beliefs with estimates of actual wages in Section 7. Conclusions follow.

\section{The Questionnaire and the Data}

The survey was conducted in 50 university faculties belonging to 32 universities distributed across 10 European countries. We asked students about their subjective expected (monthly) earnings in the following contingencies: a) starting earnings after college graduation; b) starting earnings with only a high-school degree; c) college earnings 10 years after graduation; d) high school earnings 10 years after obtaining a high-school degree. These expectations can be compared to actual earnings by level of education, which we obtain by estimating Mincerian earnings equations on country-specific micro data ${ }^{B}$. The exact formulation of the questions asked is shown in Table A4 in the Appendix.

\footnotetext{
${ }^{2}$ Wolter [2000] performs a replication of Dominitz and Manski's study for Switzerland - again with a very low number of individuals in the sample. Previous relevant research has either looked at employers' wage forecasts for the immediate future (Leonard [1982]) or has considered only the wage expectations of college jobs (Blau and Ferber [1991]).

${ }^{3}$ We use the ECHP (European Community Household Panel) dataset, an integrated European database that includes information on 14 countries. In the case of Switzerland the actual wage gap is drawn from national sources (i.e. ' the 'Labor Force Survey' (LFS)). We would like to thank our colleagues in the PuRE project (Public Funding and Private
} 
The questionnaire - which consists of only 2 pages - was distributed to college undergraduates during the academic year 1999/2000. Students were asked to fill in the questionnaire immediately before or during the first minutes of a lecture. This method delivered a very high response rate, which would have been impossible to obtain by using postal or telephone questionnaires. Overall, 6,829 questionnaires were filled in, more than $90 \%$ of the students involved.

In table A1 we report the distribution of valid questionnaires by country and university. Some countries - and some universities and faculties within countries - are more represented than others. Therefore the sample, while informative, cannot be considered as representative of the underlying population of university students in the countries considered. Since the survey was not administered and directly controlled by professional interviewers, we paid particular attention to the quality and the logical consistency of the information collected. A careful data cleaning procedure was carried out on the rough data, and the main steps followed are described below. In general, the students showed a thorough comprehension of the questionnaire and were able to report their expectations in a meaningful way.

Over 45 per cent of the filled questionnaires had no missing observations or logical inconsistencies in the answers. The remaining questionnaires contained at least one missing value or logical inconsistencies ${ }^{4}$. When missing values or inconsistencies concerned any of the crucial variables (wage expectations, gender, faculty, etc.) the individual was dropped from the final sample. In the end a total number of 5,589 valid questionnaires were retained. The frequency distribution, by country, of the dropped questionnaires is reported in column (7) of table A1 ${ }^{5} \mathrm{We}$ have also eliminated from the sample students older than 35 and those enrolled before 1994. Finally, we have removed obvious outliers by retaining only expected wage gains from college education higher than $-100 \%$ and lower than $1000 \%$ and expected college wage gains after 10 years of experience higher than $-100 \%$. These adjustments have further reduced the sample to less than 5000 individuals.

Additional checks, performed to assess the overall quality of the responses, concerned the degree of bunching of values at round numbers. In this case, as discussed by Dominitz and Manski [1996], responses though logically consistent may be perfunctory. The analysis of the distribution

Returns to Education) for help with the data. Harmon et al.(2001) provide a good description of the data and methods used to produce comparable estimates of the returns to education across Europe.

${ }^{4}$ Among the possible logical inconsistencies that we checked in the raw data we considered: age reported $v s$. implicit age at start of college; year of study vs. regular duration and expected year of graduation. Inconsistencies in the field of study (i.e. multiple and contrasting choices) and in the rate of discounting have also been considered as indicators of poor quality and the associated responses have been dropped from the final sample.

5 In two cases, Finland and Greece, due to the overall poor quality of the data and to the relatively few valid questionnaires left after the cleaning procedure, we decided to drop the country altogether. 
of values in 'open' questions - such as relative performance and wage expectations - does show the prevalence of some rounding at integer values, but does not exhibit any strong bunching or lack of care in reporting the figures.

In table A2, we report for the respondents the averages of (selected) characteristics. Average age in the sample is around 21 years, slightly higher for males than for females. A large proportion of students has held a job regularly during college (66 percent). Approximately 35 percent of college students belong to households where the father holds a university degree. This percentage falls to 23 percent when the college degree of the mother is concerned. On average, 10 per cent of the students are in the same field of study as their father and around 5 percent in that of their mother. Interestingly, both males and females are more prone to follow their fathers' than their mothers' academic choices. At the time of the survey, 50 percent of the interviewed students were in their first year of study, 24 percent in their second year, and the rest were in their third or higher year.

The majority of respondents are registered in 'economics, business and related fields' (males: 69 percent; females: 63 percent). Other fields covered are: 'social science and liberal arts' (males: 7 percent; females: 15 percent), 'natural science and engineering' (males: 13 percent; females: 5 percent), 'law' (males: 7 percent; females: 10 percent) and 'other fields' (males: 2 percent; females: 5 percent). When asked about their relative performance vis-à-vis that of their colleagues, respondents classify themselves above the theoretical average (males: 2.62; females: 2.66 ; $1=$ very good; $6=$ very poor). Finally, almost 70 percent of the respondents expect to need more years that the formal number required to complete their first degree (males: 68 percent; females: 74 percent).

\section{Students' Beliefs about their Future Wages}

Since our data are from different countries in Europe, we transform expected wages in a common unit of measure, the Euro ${ }^{6}$. Next, we define the college wage gain both at labor market entry $(D L W)$ and 10 years after entry $(D L W 10)$ as the percentage difference between the expected wage as a college graduate and the expected wage in the event of having started work right after high school.

We use the available information to regress students' beliefs about college earnings, high school earnings and the college wage gain on a set of variables, that include a) university dummies, that capture both college specific and country effects; b) field of study dummies; c) individual characteristics (age, gender, smoking habits, labor market activities) and d) family background

\footnotetext{
${ }^{6}$ In the case of UK, we have used the average exchange rate of the pound against the Euro in year 1999.

${ }^{7}$ Smoking habits are expected to capture students' discount rates (see Fersterer and Winter-Ebmer [2000]).
} 
variables (parents education and field of study). To these variables we add the year of enrolment, the gap between expected duration of the course and its regular duration, relative academic ability, and a set of dummies that capture both the alternative sources of information about future earnings and the main reasons for college choice.

Tables 1 and 2 present our results. To limit the number of rows in the tables, we do not include the estimated coefficients associated to university dummies. Most of these dummies are significantly different from zero and are plotted in Figures 1 and 2 below. We start by noticing that few of the coefficients shown in the tables are significantly different from zero. Female students expect both significantly lower college earnings and lower college wage gains. The gender difference in beliefs increases significantly with labor market experience, suggesting that, compared to males, females expect to end up in jobs with lower relative earnings growth (Table 2). Conditional on year of enrolment, older individuals have higher expected high school wages and, consequently, lower expected college wage gains.

Senior students expect lower gains than junior students. Compared to students enrolled in 1999, for example, students who enrolled before 1998 expect, ceteris paribus, about 4 percentage points less in terms of college wages at labor market entry. Assuming that endogenous selection weeds out individuals with higher costs and/or lower expected benefits from college, the negative effect of seniority in college on the expected college wage possibly identifies a learning effect: as students go through their curricula, they become more realistic in their expectations about future incomes. An alternative explanation is that senior students take the questionnaire more seriously. These results are similar to the learning effects Betts [1996] finds for the U.S.

Students who expect to take longer than required to complete their degree have also lower expected college wages but about the same expected high school wage, both at labor market entry and after 10 years of experience. Clearly, late completion is a negative labor market signal. Conditional on the year of enrolment, one could think that students who plan to finish later could foresee higher nominal earnings because they incorporate the rate of inflation in their expectations ${ }^{8}$. The negative impact of late completion on expected college wages, together with no significant effect of late completion on expected high-school wages is inconsistent the view that respondents inflate their future expectations for college wages: If late completion is a quality signal, students should expect both lower college and high-school wages, incorporating inflation would only counteract the negative effect on college wages. This is not what we found.

Family background matters for expectations, and having a mother with a college degree leads to a $3.3 \%$ or to a $4 \%$ increase in the expected college wage, depending on whether the

\footnotetext{
${ }^{8}$ We thank Julian Betts for bringing this point to our attention.
} 
expectations refer to the start of a career or to 10 years after labor market entry. Interestingly, the father's education is never significant in these regressions.

Among alternative ways of learning about future wages (whether from university publications, from career centers, from the daily press or from personal conversations with friends and acquaintances) only learning from the daily press and from personal conversations positively and significantly affect expectations. Broadly speaking, there seems to be no clear pattern relating expected wages and wage gains to the main reasons for selecting the current college.

Expected wages and wage gains turn out to be significantly different across fields of study. Compared to a major in economics and business (the constant term), a major in humanities is expected to pay-off considerably less, both in absolute and in relative terms. The relative decline is lower than the absolute decline because students in the humanities also expect lower earnings in the case of having started to work right after high school. In contrast, a technical major is expected to carry a positive payoff. This gain, however, is not significantly different from zero. Importantly, perceived relative ability matters, and students who rank themselves above the average in their class have consistently higher expected college earnings.

An important aspect of the expected return from college is the probability of finding an appropriate job after graduation. The mismatch between the type of qualifications acquired at school and the job can take two forms: over-education and unemployment. Unemployment rates have been persistently high in most European countries since the early 1980s and in some countries the probability of unemployment has increased not only among the unskilled but also among the educated (see Nickell and Bell [1995]). When unemployment is a possibility, the expected return to college needs to be adjusted to take this event explicitly into account (Nickell [1979]).

We have asked students to evaluate their own chances of getting an appropriate job after graduating. We have also asked whether these chances have improved by college education with respect to having only a high school degree. Since the answers to these questions can be ranked from 'very poor' to 'very good' and from 'much worse' to 'much better', we estimate an ordered probit model that relates job prospects to individual and college characteristics. The results are presented in Table 3 and can be summarized as follows: a) graduates in the humanities and in law have significantly worse absolute and relative job prospects as compared to graduates in economics and business; b) prospects increase significantly when parents have a college degree and have studied in the same field, which clearly indicates the presence of network effects; c) females have worse job prospects than males; d) job prospects are also worse for students who plan to finish later than required; e) information from special reports, the daily press and from personal communication significantly improve the probability of finding an appropriate job. The relevance of personal 
communication is evidence that family and/or personal networks matter; f) working while at school improves the chances of finding an appropriate job after graduation.

It is interesting to compare wage expectations with expectations about job prospects. Family networks (parents have a college degree and have studied the same field) appear to be very important in finding a new job, but not important for wage expectations. Likewise, students who have worked during college and have chosen their field mainly because of personal interest expect to have better job opportunities, but not better wages. In the case of other characteristics -gender, relative performance, year of enrolment and the gap between expected and required years of study expectations about wage and job prospects go nicely hand in hand: for instance, females expect both lower wages and more difficulties to find a job. Higher (lower) expected wages and better (worse) job prospects are consistent with a higher (lower) relative demand for students with these characteristics rather than with a lower (higher) relative supply.

With the only exception of university dummies, the estimates in Tables 1 and 2 are based on the assumption that (estimated) coefficients do not vary across countries. We check this assumption by fitting the same empirical model - exclusively for wage gains - separately for Germany, Italy, Portugal and Switzerland, the countries for which we have a reasonable number of observations. The results are reported in Tables 4 and 5. An interesting finding is that the distribution of wage gains by field varies significantly by country. While in Portugal it is students of natural sciences and engineering who expect to fare worse that students of economics and business, in Germany and Switzerland it is students in humanities and law who expect relatively lower college wage gains.

\section{Differences across countries and institutions}

Conditional on individual, field of study and family background variables, university dummies capture the country by institutions effects on expected wages and on expected wage gains. We run our regressions by gender and plot the estimated coefficients of these dummies in Figures 1 and 2. Figure 1 considers the wage gain of males and females both at labor market entry and 10 years after entry. We notice that a) males have on average higher expectations; b) German and Portuguese students expect higher than average wage gains, while Italian students expect less than average gains. Figure 2 presents the same information in a different way, by plotting for each gender the wage gain 10 years after entry against the wage gain at entry. Simple inspection of the data suggests that, for any current wage gain, males expect substantially higher wage gains 10 years after entry. 
Based on these regressions, we recover the estimated dummies for the expected college wage gain at entry and after 10 years of experience. These dummies vary by university, country and gender. Using the two-step estimation method discussed by Card and Krueger (1990), we pool the estimated dummies 9 and regress them on a set of variables capturing country specific long-run economic performance and both schooling and labor market institutional features. In practice, the following variables have been used: a gender dummy; the 1976-1992 average annual rate of growth of labor productivity in the private sector; the degree of tracking and stratification in secondary education; the Kaitz index, that measures the minimum wage as a percentage of the average wage; union density and the share of public employment in total employment. The values taken by these explanatory variables in each country are shown in Table A3 in the Appendix.

The growth in labor productivity is a typical demand side variable. We expect a positive correlation between the college specific expected wage gain and labor productivity growth for at least three reasons. First, skill biased technical change that increases productivity growth can affect the expected gain by shifting out the relative demand for skilled labor (see Berman et al. [1994]). Second, labor productivity growth could be driven, at least in part, by the growth in the capital labor ratio; if capital and skill are complements in production, this would generate an upward shift in the relative demand for skills (see Krusell et al [2000]). Last but not least, both a higher college wage gain and faster skill biased technical progress could be induced by the relative abundance of well educated labor (Acemoglu [2000]).

The degree of stratification of secondary schools differs across European countries. Shavit and Muller [1998], for instance, distinguish between stratified and comprehensive systems of secondary education. In stratified systems (Germany, Austria, The Netherlands, Switzerland) students are separated early on into tracks which differ markedly in the curricula and in the probability that students go on to tertiary education. In comprehensive systems (as it is the case for the rest of the countries in our sample), tracking starts later and there are smaller differences both among tracks and in the odds of continuation to tertiary education. The degree of differentiation of secondary schools is likely to affect the labor market returns of high school and college graduates, and to influence expected wage gains from college. In particular, we expect that stratification, by sorting individuals of different ability to different school types, helps increasing the college wage gain $\frac{10}{10}$. We measure stratification with a dummy, that is equal to 1 in countries with a stratified system and to zero elsewhere.

Labor market institutions also affect the expected college wage gain. In countries where the wage structure is more compressed, either because of a relatively high minimum wage or because of

\footnotetext{
${ }^{9}$ These college dummies are defined with respect to a baseline university, that we choose to be Berlin.
} 
high union density, the expected college wage gain is likely to be lower than in countries with a more dispersed wage distribution. Since many public sector jobs are filled by college graduates, the relative abundance of these jobs can also affect expectations.

We add to the list of explanatory variables a set of variables that vary both among countries and among the universities in the same country. These variables are meant to capture within country differences in perceived college quality and selectivity. We have asked the interviewers at each university where we collected the individual questionnaire the following: a) to state whether the university has an official admission procedure for students in the specific field (1 if the procedure exists; 0 otherwise); b) to compare this procedure to the national average $(0-2$ if the procedure is less, as restrictive or more restrictive); c) to compare the prestige in education of the university to the national average (0-2 for lower, comparable or higher as the national average); d) to compare the prestige in research of the university to the national average (0-2 for lower, comparable or higher as the national average); e) to indicate whether the university is private or public. We expect that students in colleges with a stricter admission standard and a better education and research reputation have better labor market opportunities and a higher expected wage gain from college education.

We use generalized least squares methods, adopting as weights the inverse of the sampling variance of the estimated university dummies. Since most variables vary by country but not by college, we correct the standard errors by allowing the possibility of no independence of errors within clusters (see Moulton [1990]). Results are reported in Table 6. We find evidence that expected wage gains from college are higher in countries with faster productivity growth. Expected gains, both at labor market entry and 10 years later, are significantly higher in countries where secondary schools are more differentiated (Germany, Austria, Switzerland) and the share of public employment is higher, and significantly lower in countries with high union density and a relatively high minimum wage. Most of these results are in line with our a priori expectations.

There is little evidence, however, that college specific variables significantly influence expected wage gains from college education. In particular, we find no evidence that perceived college quality, either in education or in research, matters for students' expectations. The main exception is the relative strictness of the admission procedure, that positively affects expected wage gains 10 years after labor market entry.

\footnotetext{
${ }^{10}$ See Brunello and Giannini [2000] for a discussion of the economic consequences of school design.
} 


\section{Is there a trade off between the expected college wage at entry and the future college wage gain?}

When the labor market is loose and youth unemployment is significant, as it has happened in several European countries during the past fifteen years, college graduates can experience difficulties in finding a match with a high paying job just after completing college. In many cases, graduates can expect to start with an entry job, that offers a relatively low salary, and to experience fast earnings growth over time, as they shift to better matches. Alternatively, when education and training are complements and graduates expect to find jobs in sectors with high productivity growth and substantial on the job training, the expected entry wage can be relatively low because of the investment in training but earnings growth can be fast because of the accumulated human capital. In both cases, we expect to find a negative relationship, or a trade off, between the expected entry wage after college $\left(W_{-} C o l l\right)$ and expected college earnings growth 10 years after entry $\left(\Delta W_{-} C o l l\right)$.

We test whether such a relationship exists in the data by augmenting the list of explanatory variables in the regressions in Tables 1-2 with $W_{-}$Coll and by using $\Delta W_{-}$Coll as the dependent variable. While cross country differences in price levels are controlled by university dummies, individual effects are controlled by the full set of characteristics used in the previous regressions. The empirical analysis is performed both for the full sample and separately for the four countries where we have enough data, Germany, Italy, Portugal and Switzerland. The estimated coefficient of $W_{-}$Coll is shown in Table 7.

Our results suggest that college students who expect a faster earnings growth 10 years after entry also expect a relatively low entry wage. This "trade-off" is significant in the full sample and particularly strong in Portugal and Italy. Interestingly, both Portugal and Italy are the countries in our sample that have experienced the faster productivity growth in the past fifteen years (see Table A3 in the Appendix). A possible interpretation is that fast productivity growth has been accompanied in these countries by a relatively fast accumulation of human capital in college related jobs.

\section{The variability of expectations within institutions}

In Section 4 we have associated the differences in expected wage gains across countries and universities to country-specific and university-specific effects, including labor market institutions and college design. Our data show that significant differences in expected wages exist also within universities and fields of study. For each university and field of study we have computed the 
coefficient of variation of individual expected wage gains. We find that the median expected college - high school wage gain is $81 \%$ at labor market entry and $114 \% 10$ years after entry. The variability of expectations is high. In particular, the ratio of the $90^{\text {th }}$ to the $10^{\text {th }}$ percentile is 2.80 for expected wages at labor market entry and 2.97 for expected wages ten years after entry. This variance is significantly higher than that reported by Betts (1996) for the wage expectations of U.S. college students, that is typically just below 2 . This is a remarkable finding, given the general view that wage dispersion is higher in the U.S. than in Europe. One possible explanation is that U.S. college students estimate future wages more precisely than their European counterparts 11 .

How do we explain the observed variation in expected wage gains? Are expectations more precise when students have better access to information about job prospects and wages from career centers and similar structures? Table 8 presents the results of regressions that have as the dependent variable the coefficient of variation of the college - high school expected wage gain, either at labor market entry or 10 years after entry; variation is taken always within a field and place. Among the regressors, we use the coefficient of variation of actual college earnings $\frac{12}{12}$. Interestingly, actual wage dispersion has no significant impact on the variance of wage expectations. On the other hand, the availability of information about college wages plays a role in explaining the observed variability of expectations. In particular, the dispersion is lower in universities and fields of study where students have better access to wage information from university career centers. Common information obviously increases the precision of estimated future wages. When information is gathered from personal communication, however, the variance of estimates increases, which reflects the idiosyncrasy of these personal contacts. The variability of expectations is lower when the share of female students is higher, higher in private universities and lower in colleges that have strict admission criteria. The latter finding is consistent with the view that admission standards sort individuals by ability (Betts [1998]) and reduce the heterogeneity in the talent of admitted students.

\section{Are students' expectations accurate?}

In this section we compare students' expectations about college wage gains with actual wage gains. The nature of this comparison is speculative and some care should be used in interpreting the results, since our expectation data do not represent accurately the population of college students. Data on actual college wage gains are drawn from the European Community Household Panel

\footnotetext{
${ }^{11}$ Notice, however, that we ask students about their expected wages, rather than about their expectations about national average wages, as done by Betts.

${ }^{12}$ Ideally, we would like to use the coefficient of variation of actual high-school earnings as well, but this variable turns out to be highly collinear with the coefficient of variation of actual college wages.
} 
(ECHP) - a household survey covering 14 European countries - and from national surveys (in the case of Switzerland). To improve comparability across countries, we only retain data on the expected wage gains of students enrolled in business and economics, that cover the large majority of our sample. The expected college gain has been measured both at the start of the career as well as after 10 years of work experience, though only wage gains at start of the career are reported ${ }^{13}$. In Figures 3 and 4 we compare expected wage gains at start, separately for males and females, with a similar estimate of the actual wage gain for each country included in the sample. In particular, we plot the mean, the 10th and the 90th percentile of expected wage gains and the mean of actual college wage gains, estimated from the ECHP or from national surveys. Actual wage gains estimates are obtained by using the fitted values from regressions (separately for males and females) of the log hourly wage on education dummies (high school and college), work experience, work experience squared and interactions among these variables.

We notice that expected wage gains differ considerably across countries both in the mean and in the dispersion. Although in most countries the 90th - 10th percentile of the distribution of expected wage gains falls within a reasonable range, in the United Kingdom, Germany and Portugal the expected wage gain exhibits both a significantly higher mean and a wider dispersion, irrespective of gender. Why is the dispersion of expected wage gains higher in these countries? One obvious explanation is the greater dispersion of actual earnings that characterizes both the United Kingdom and Portugal (see OECD [1994]). The case of Germany is more puzzling, however, because wage dispersion is rather moderate in this country.

The main message in the figures is that the average expected college wage gains of the economics and business students in our sample is consistently higher than the overall estimated average actual wage gain. In some countries, particularly for females, the actual gain lies even below the lower bound of the $90^{\text {th }}-10^{\text {th }}$ percentile range (i.e. Austria, Germany and Sweden). Why are expected gains associated to higher education so much higher than actual gains? One obvious reason is that economics and business students have better labor market prospects than other college students $\frac{14}{14}$. Since we are comparing the expectations of the former with the actual wages of all college students, this composition effect is likely to bias upwards the difference between expected and actual gains. Another reason might have to do with the fact that we are comparing expected monthly wage gains with actual hourly wage gains. If college graduates work longer hours than their high school counterparts, this could reduce the actual hourly wage gain 15 .

\footnotetext{
${ }^{13}$ The comparison between expected and actual wage gains 10 years after labor market entry does not yield new insights and is not presented to save space.

${ }^{14}$ Results, however, do not change in a qualitative way if we include students form other disciplines as well.

${ }^{15}$ Notice that our results for actual wage gains are remarkably similar when we use alternative datasources, such as the ECHP and national household surveys. The results are available from the authors upon request.
} 
An additional explanation is that students in general tend to be over-optimistic, a typical result in this literature. Betts [1996, p. 39], for instance, finds that students overestimate actual college wage gains by approximately 10 percent. Likewise, Webbink and Hartog [1999] find that actual wages are 10 percent short of expected wages. Compared to these studies, however, our findings seem to suggest that the over-estimation is much larger, on average, than 10 percent.

\section{Conclusions}

In this descriptive paper we have used the replies to the same questionnaire by more than 6000 college students all over Europe to carry out the first systematic study of the wage expectations of European college students. We have studied the determinants of wage expectations and expected employment probabilities, the variability of these expectations within a field of study and their variation across universities and fields. We have also examined the trade-off between expected starting wages and wage growth and contrasted expected returns to college education with actual returns estimated form country-specific micro-data. Our main findings can be summarized as follows:

1) expected college wages and college wage gains in our European sample are significantly related to the field of study, gender, age, seniority in college, the gap between expected and required years of study, perceived student relative ability and family background;

2) expected absolute and relative job prospects depend on the field of study and also on family background, which suggests that personal networks are important in the European labor market for college graduates;

3) students with higher perceived relative ability who expect to complete college within the required number of years have both higher expected wages and better expected job prospects;

4) country and college specific average college wage gains are higher in countries with a higher long run rate of productivity growth, a higher share of public employment, with a stratified schooling system and relatively strict procedures of college admission, and lower in countries where both union density and the Kaitz index for the minimum wage are higher;

5) there is a evidence of a significant trade off between expected college wages at labor market entry and earnings growth 10 years after entry; 
6) the variability of expected college wage gains within college and field of study is higher than the variability found by Betts in his sample of American students, in spite of the fact that European labor markets exhibit on average lower earnings inequality than the US labor market;

7) expected college wage gains in our sample are substantially higher, on average, than actual college wage gains.

While our sample covers a substantial number of college students, much could be done to further improve our knowledge of how college students form their expectations. A more balanced coverage of universities and fields of study within Europe would be the most obvious extension of the current research. In spite of the limits of the current dataset, we feel that interesting regularities have been discovered that help highlight the individual decisions to enroll in college in Europe ${ }^{16}$.

\footnotetext{
${ }^{16}$ See Lanot et al. [2000] for a discussion of college enrolment in Europe.
} 


\section{References}

Acemoglu, D., (2000), Technical Change, Inequality and the Labor Market, NBER Working paper \# 7800, Cambridge, MA.

Altonji, Joseph G. (1993): The Demand for and Return to Education When Education Outcomes Are Uncertain, Journal of Labor Economics 11/1, 48-83.

Berman, E., Bound, J. and Griliches, Z. (1994), "Changes in the demand for skilled labor within US manufacturing industries: evidence from the annual survey of manufactures", Quarterly Journal of Economics, 109, 367-397.

Betts, Julian R. (1996): What Do Students Know About Wages? Evidence from a Survey of Undergraduates, Journal of Human Resources 31/1, 27-56.

Betts, J., (1998), The Impact of Educational Standards on the Level and Distribution of Earnings, The American Economic Review, 88, 1, 266-275.

Blau, Francine D. and Marianne Ferber (1991): Career Plans and Expectations of Young Women and Men, Journal of Human Resources 26, 581-607.

Brunello, G., Comi, S. and Lucifora, C., The college wage gap in 10 European countries: evidence from two cohorts, Fondazione ENI Enrico Mattei Working paper 85-00, 2000

Brunello, G. and Giannini, M. (2000), Stratified or comprehensive? The economic efficiency of school design, ISER Discussion Paper, Essex University, 2000-32

Card, D. and Krueger, A., (1990), Does School Quality Matter? The Journal of Political Economy, $100,1,1-40$.

Carvajal, Manuel J. et al. (2000) : Inter-Gender Differentials Between College Students' Earnings Expectations and the Experience of Recent Graduates, Economics of Education Review 19, 229243.

Cook, Anthony and Janet Leckey (1999): Do Expectations Meet Reality? A Survey of Changes in First-Year Student Opinion, Journal of Further and Higher Education 23, 157-171.

Dominitz, Jeff and Charles F. Manski (1996): Eliciting Student Expectations of the Returns to Schooling, Journal of Human Resources 31/1, 1-26.

Dominitz, Jeff and Charles F. Manski (1997): Perceptions of Economic Insecurity, Public Opinion Quarterly 61, 261-287.

Fersterer, Josef and Rudolf Winter-Ebmer (2000): Smoking, Discount Rates, and Returns to Education, IZA Bonn, Discussion Paper n.126.

Harmon, Colm, Walker, Ian and Niels Westergard-Nielsen (2001) (eds), Education and Earnings in Europe: A Cross Country Analysis of the Returns to Education, Edward Elgar 
Krusell, P., Ohanian, L., Rios-Rull, J. and Violante, G., (2000), Capital - Skill Complementarity and Inequality: A Macroeconomic Analysis, Econometrica, 1029-1053.

Lanot, Gauthier, Winter-Ebmer, Rudolf and Aniela Wirz (2000): Public Funding and Enrolment into Higher Education in Europe, mimeo, University of Linz, Austria.

Leonard, Jonathan S. (1982): Wage Expectations in the Labor Market: Survey Evidence on Rationality, Review of Economics and Statistics 64, 157-161.

Manski, Charles F. (1993): Adolescent Econometricians: How Do Youth Infer the Returns to Schooling?, in Studies of Supply and Demand in Higher Education, eds. C. Clotfelder and M. Rothschild, Chicago: University of Chicago Press, 43-60.

Moulton, B. (1990), "An Illustration of a Pitfall in Estimating the Effects of Aggregate Variables on Micro Units", The Review of Economics and Statistics, 334-338.

Nickell, S. (1979), Education and Lifetime patterns of Unemployment, Journal of Political Economy, S117-S131.

Nickell, S. and Bell, B., (1995), The collapse in demand for the unskilled and unemployment across the OECD, Oxford Review of Economic Policy, 11, 1, 40-62.

OECD (1994), The Jobs Study, Paris.

Shavit, Y. and Muller, W. (1998), From School to Work, Clarendon Press.

Webbink, Dinand and Joop Hartog (1999): Can Students Predict their Starting Salary? Yes!, mimeo, University of Amsterdam.

Wolter, Stefan C. (2000): Student Expectations of Returns on Education - Results from Switzerland and the United States, Kyklos, 51-69. 
Table 1: Expected college and high school wages and expected wage gain at labor market entry

\section{College wage High-school wage Wage gain}

Base: Business \& Economics

Humanities and liberal arts

$-0.093$

$(0.020)^{* *}$

$-0.058$

$-0.071$

0.050

$(0.020)^{* *}$

$(0.051)$

Natural sciences and engineering

$(0.029)$

0.002

0.151

$-0.028$

$(0.034)$

(0.091)

Law

$(0.027)$

0.051

$(0.025)^{*}$

$-0.045$

$(0.063)$

Other fields

$-0.022$

$-0.001$

$-0.061$

(0.036)

$(0.034)$

(0.078)

Father attended college

0.004

$(0.013)$

$-0.018$

0.061

$(0.014)$

(0.037)

Mother attended college

0.033

0.026

0.013

$(0.015)^{*}$

(0.016)

(0.044)

Father studied same discipline

$-0.005$

0.008

$-0.031$

(0.017)

(0.018)

(0.050)

Mother studied same discipline

$-0.026$

(0.023)

$-0.045$

0.090

(0.024)

(0.079)

Age

0.004

(0.002)

0.018

$-0.035$

$(0.002)^{* *}$

$(0.006)^{* *}$

Female

$-0.096$

$(0.012)^{* *}$

$-0.100$

$-0.029$

$(0.012)^{* *}$

(0.030)

Gap betw. exp. \& nec. years of study

$-0.028$

$-0.006$

$-0.043$

$(0.006)^{* *}$

(0.006)

$(0.015)^{* *}$

Info from univ. publications $(0 / 1)$

0.007

(0.016)

0.030

$-0.058$

(0.018)

(0.039)

Info from univ. career center $(0 / 1)$

$-0.008$

(0.023)

$-0.017$

$-0.023$

(0.024)

(0.048)

Info from special reports $(0 / 1)$

$-0.003$

(0.019)

$-0.016$

0.003

(0.020)

(0.047)

Info from daily/weekly press $(0 / 1)$

0.023

$-0.004$

0.058

$(0.011)^{*}$

(0.012)

(0.031)

Info from pers. communication $(0 / 1)$

0.004

(0.011)

0.000

$-0.011$

(0.012)

(0.031)

Reason select school: proximity $(0 / 1)$

$-0.001$

$-0.057$

0.153

(0.024)

(0.030)

(0.092)

Reason select school: reputation $(0 / 1)$

$-0.021$

(0.022)

$-0.027$

0.010

(0.024)

(0.061)

Reason select school: costs $(0 / 1)$

$-0.009$

$-0.071$

0.184

(0.030)

(0.039)

(0.119)

Reason select school: income (0/1)

0.008

$(0.016)$

$-0.019$

$(0.020)$

0.022

(0.052) 
Reason select school: assigned (0/1)

Interest in subject $(0 / 1)$

Enrolled in 1998

Enrolled before 1998

Relative performance (0-6)

Hours worked while at school

Smoker (0/1)

Number of observations

Adjusted R-squared

Robust standard errors in parentheses

$*$ significant at $5 \%$; * significant at $1 \%$
$-0.068$

(0.035)

$-0.025$

(0.016)

$-0.028$

$(0.015)$

$-0.038$

$(0.019)^{*}$

0.033

$(0.007)^{* *}$

0.000

$(0.001)$

$-0.011$

$(0.013)$

4405

0.64
$-0.001$

$(0.042)$

$-0.021$

(0.020)

$-0.015$

(0.016)

$-0.022$

(0.020)

0.020

$(0.007)^{* *}$

0.001

(0.001)

$-0.002$

(0.014)

4405

0.64
$-0.124$

(0.114)

$-0.025$

(0.052)

$-0.034$

(0.041)

$-0.061$

(0.047)

0.015

(0.022)

$-0.002$

(0.002)

$-0.016$

(0.038)

4405

0.16 
Base: Business \& Economics

Humanities and liberal arts

$-0.088$

$-0.068$

$(0.025)^{* *}$

$(0.024)^{* *}$

$(0.080)$

Natural sciences and engineering

0.004

$-0.017$

0.116

$(0.036)$

(0.036)

$(0.114)$

Law

$-0.023$

0.041

$-0.116$

$(0.029)$

(0.028)

(0.096)

Other fields

$-0.063$

$(0.044)$

$-0.046$

$-0.066$

$(0.040)$

$(0.148)$

Father attended college

0.026

$-0.011$

0.089

$(0.017)$

(0.016)

$(0.060)$

Mother attended college

0.040

0.026

0.063

$(0.019)^{*}$

(0.018)

$(0.068)$

Father studied same discipline

0.008

0.026

$-0.052$

$(0.023)$

$(0.021)$

$(0.082)$

Mother studied same discipline

$-0.037$

(0.031)

$-0.029$

$-0.038$

(0.028)

$(0.109)$

Age

0.002

0.017

$-0.048$

$(0.003)$

$(0.003)^{* *}$

$(0.009)^{* *}$

Female

$-0.204$

$-0.173$

$-0.160$

$(0.015)^{* *}$

$(0.014)^{* *}$

$(0.048)^{* *}$

Gap betw. exp. \& nec. years of study

$-0.038$

$-0.009$

$-0.062$

$(0.008)^{* *}$

(0.008)

$(0.024)^{*}$

Info from univ. publications $(0 / 1)$

$-0.001$

0.028

$-0.039$

$(0.020)$

$(0.020)$

$(0.070)$

Info from univ. career center $(0 / 1)$

0.021

$-0.006$

0.110

$(0.030)$

(0.029)

$(0.103)$

Info from special reports $(0 / 1)$

$-0.001$

$-0.007$

$-0.022$

$(0.025)$

(0.024)

(0.086)

Info from daily/weekly press $(0 / 1)$

0.040

0.005

0.128

$(0.014)^{* *}$

$(0.013)$

$(0.047)^{* *}$

Info from pers. communication $(0 / 1)$

0.039

0.027

0.010

$(0.014)^{* *}$

(0.014)*

(0.047)

Reason select school: proximity $(0 / 1)$

$-0.047$

$-0.082$

0.093

$(0.029)$

$(0.034)^{*}$

$(0.127)$

Reason select school: reputation $(0 / 1)$

0.013

$-0.025$

0.093

$(0.028)$

(0.028)

$(0.104)$

Reason select school: costs $(0 / 1)$

$-0.017$

$-0.041$

0.060

(0.037)

$(0.045)$

$(0.146)$

Reason select school: income $(0 / 1)$

0.018

$-0.016$

0.071

$(0.021)$

(0.022)

(0.081) 


$\begin{array}{lccc}\text { Reason select school: assigned (0/1) } & -0.132 & -0.002 & -0.293 \\ \text { Interest in subject (0/1) } & (0.037)^{* *} & (0.050) & (0.175) \\ & -0.038 & -0.020 & -0.106 \\ \text { Enrolled in 1998 } & (0.020) & (0.022 & (0.077) \\ & -0.050 & -0.024 & -0.105 \\ \text { Enrolled before 1998 } & (0.020)^{*} & (0.018) & (0.067) \\ & -0.034 & -0.012 & -0.127 \\ \text { Relative performance (0-6) } & (0.024) & (0.023) & (0.073) \\ & 0.062 & 0.037 & 0.076 \\ \text { Hours worked while at school } & (0.009)^{* *} & (0.008)^{* *} & (0.037)^{*} \\ & 0.001 & 0.002 & 0.000 \\ \text { Smoker (0/1) } & (0.001) & (0.001) & (0.004) \\ & -0.017 & 0.004 & -0.095 \\ \text { Number of observations } & (0.017) & (0.015) & (0.064) \\ \text { Adjusted R-squared } & 4216 & 4122 & 4102\end{array}$

Robust standard errors in parentheses

$*$ significant at $5 \%$; * significant at $1 \%$ 
Table 3: Expected job prospects after graduation. Absolute and relative to high school job prospects.

Base: Business \& Economics

Humanities and liberal arts

$-0.468$

$(0.066)^{* *}$

$-0.231$

Natural sciences and engineering

0.031

$(0.062)^{* *}$

(0.129)

0.190

$-0.243$

(0.106)

Law

$(0.068)^{* *}$

$-0.236$

Other fields

$-0.016$

$(0.073)^{* *}$

(0.103)

$-0.118$

(0.087)

Father attended college

0.083

0.100

(0.042)*

$(0.042)^{*}$

Mother attended college

0.101

0.090

$(0.046)^{*}$

(0.046)

Father studied same discipline

0.143

0.006

$(0.059)^{*}$

(0.062)

Mother studied same discipline

0.065

(0.075)

0.005

$(0.080)$

Age

0.004

(0.009)

$-0.002$

(0.008)

Female

$-0.185$

0.021

$(0.036)^{* *}$

(0.036)

Gap betw. exp. \& nec. years of study

$-0.071$

$-0.049$

$(0.021)^{* *}$

$(0.020)^{*}$

Info from univ. publications $(0 / 1)$

$-0.013$

(0.047)

0.037

(0.049)

Info from univ. career center $(0 / 1)$

0.114

$-0.022$

(0.075)

(0.078)

Info from special reports $(0 / 1)$

0.226

0.057

$(0.064)^{* *}$

(0.071)

Info from daily/weekly press (0/1)

0.139

0.097

$(0.034)^{* *}$

$(0.034)^{* *}$

Info from pers. communication $(0 / 1)$

0.104

$(0.035)^{* *}$

0.108

$(0.034)^{* *}$

Reason select school: proximity $(0 / 1)$

0.074

0.051

(0.074)

$(0.067)$

Reason select school: reputation $(0 / 1)$

0.011

0.016

(0.068)

(0.067)

Reason select school: costs $(0 / 1)$

$-0.076$

$-0.077$

(0.099)

(0.094)

Reason select school: income $(0 / 1)$

0.320

$(0.054)^{* *}$

0.085

$(0.051)$ 
Reason select school: assigned (0/1)

0.156

$-0.104$

$(0.114)$

$(0.100)$

Interest in subject $(0 / 1)$

0.220

0.099

$(0.051)^{* *}$

$(0.049)^{*}$

Enrolled in 1998

$-0.172$

0.002

$(0.047)^{* *}$

(0.046)

Enrolled before 1998

$-0.203$

$-0.056$

$(0.058)^{* *}$

(0.056)

Relative performance (0-6)

0.239

0.107

$(0.023)^{* *}$

$(0.021)^{* *}$

Hours worked while at school

0.011

$-0.003$

$(0.003)^{* *}$

(0.002)

Smoker $(0 / 1)$

0.041

$-0.094$

$(0.041)$

$(0.040)^{*}$

Number of observations

4389

4362

Robust standard errors in parentheses

$*$ significant at 5\%;** significant at $1 \%$ 
Table 4: Expected college and high school wages and expected wage gain at labor market entry. By country

Base: Business \& Economics

Humanities and liberal arts

$\begin{array}{llrl}-0.184 & -0.044 & 0.028 & -0.126 \\ (0.043)^{* *} & (0.192) & (0.052) & (0.046)^{* *}\end{array}$

Natural sciences and engineering

0.121

(0.071)

$-0.094$

$(0.074)$

$-0.498$

$-0.107$

$(0.078)^{* *}$

(0.066)

Law

Other fields

Father attended college

0.000

$(0.000)$

$-0.182$

$(0.100)$

0.069

$-0.194$

(0.047)

$(0.038)^{* *}$

$-0.121$

$(0.061)^{*}$

$-0.146$

(0.101)

$-0.074$

(0.108)

$-0.065$

(0.078)

0.040

(0.027)

0.046

(0.039)

$-0.009$

$-0.021$

(0.034)

(0.028)

Mother attended college

0.001

$(0.033)$

0.047

(0.049)

0.109

$-0.005$

$(0.036)^{* *}$

(0.036)

Father studied same discipline

$-0.019$

0.037

(0.045)

0.005

$-0.004$

(0.040)

$-0.074$

(0.063)

$(0.040)$

(0.050)

Mother studied same discipline

0.028

(0.047)

$-0.000$

0.011

(0.006)

(0.014)

$-0.034$

(0.052)

$-0.032$

(0.069)

$-0.010$

0.007

(0.005)

Female

$-0.123$

$(0.028)^{* *}$

$-0.104$

$(0.032)^{* *}$

$-0.124$

$-0.069$

$(0.026)^{* *}$

$(0.027)^{* *}$

Gap betw. exp. \& nec. years of study

$-0.012$

(0.022)

$-0.042$

$-0.020$

$-0.000$

$(0.020)^{*}$

(0.025)

(0.013)

Info from univ. publications $(0 / 1)$

0.028

(0.034)

0.003

$(0.055)$

$-0.008$

(0.039)

$-0.004$

(0.032)

Info from univ. career center $(0 / 1)$

$-0.043$

(0.039)

0.102

(0.067)

$-0.040$

$-0.075$

(0.100)

(0.044)

Info from special reports $(0 / 1)$

0.022

(0.046)

0.022

(0.057)

$-0.008$

0.100

(0.035)

(0.080)

Info from daily/weekly press $(0 / 1)$

0.081

0.012

$-0.013$

0.012

$(0.026)^{* *}$

(0.032)

(0.026)

$(0.023)$

Info from pers. communication $(0 / 1)$

0.007

(0.026)

0.032

(0.032)

0.005

0.001

(0.031)

(0.023)

Reason select school: proximity $(0 / 1)$

0.026

(0.040)

$-0.017$

(0.083)

0.006

$-0.003$

(0.061)

(0.060)

Reason select school: reputation $(0 / 1)$

$-0.010$

$-0.127$

(0.118)

$-0.017$

0.182

(0.041)

(0.190)

Reason select school: costs $(0 / 1)$

$-0.000$

(0.046)

0.228

$(0.103)^{*}$

0.003

$-0.151$

(0.088)

(0.078)

$-0.007$

0.067

0.002

0.005 


$\begin{array}{lcccc} & (0.035) & (0.059) & (0.037) & (0.044) \\ \text { Reason select school: assigned (0/1) } & -0.089 & -0.070 & 0.012 & -0.017 \\ & (0.045)^{*} & (0.176) & (0.099) & (0.064) \\ \text { Interest in subject (0/1) } & -0.026 & 0.052 & -0.019 & 0.003 \\ & (0.032) & (0.061) & (0.036) & (0.041) \\ \text { Enrolled in 1998 } & -0.024 & 0.031 & 0.023 & -0.016 \\ & (0.042) & (0.063) & (0.034) & (0.045) \\ \text { Enrolled before 1998 } & -0.039 & 0.010 & -0.039 & -0.023 \\ & (0.054) & (0.044) & (0.037) & (0.052) \\ \text { Relative performance (0-6) } & 0.042 & 0.048 & 0.027 & 0.021 \\ & (0.015)^{* *} & (0.017)^{* *} & (0.021) & (0.017) \\ \text { Hours worked while at school } & 0.001 & 0.004 & 0.003 & 0.000 \\ & (0.002) & (0.002) & (0.002) & (0.002) \\ \text { Smoker (0/1) } & 0.034 & -0.050 & -0.023 & -0.035 \\ & (0.023) & (0.036) & (0.035) & (0.028) \\ \text { Constant } & 7.767 & 7.164 & 7.995 & 8.237 \\ & (0.151)^{* *} & (0.308)^{* *} & (0.176)^{* *} & (0.143)^{* *} \\ \text { Number of observations } & 1025 & 529 & 848 & 526 \\ \text { Adjusted R-squared } & 0.09 & 0.10 & 0.11 & 0.10\end{array}$

Robust standard errors in parentheses

$*$ significant at $5 \%$; ** significant at $1 \%$ 
Table 5. Expected college and high school wages and expected wage gain 10 years after labor market entry. By country.

Base: Business \& Economics

Humanities and liberal arts

$\begin{array}{lr}-0.192 & 0.098 \\ (0.046)^{* *} & (0.159)\end{array}$

$-0.118$

$-0.230$

Natural sciences and engineering

-0.038
$(0.093)$

$-0.132$

$(0.082)$

$(0.057)^{* *}$

Law

$$
-
$$

0.038

$-0.153$

$(0.268)$

(0.071)*$$
-0.037
$$$$
-0.185
$$

Other fields

Father attended college

$$
-0.23
$$$$
0.068
$$$$
(0.031)^{*}
$$$$
-0.010
$$$$
\text { (0.037) }
$$$$
(0.105)
$$$$
\text { (0.054) }
$$

Mother attended college

Father studied same discipline

$-0.045$

(0.048)

$-0.002$

$(0.146)$

$-0.201$

(0.146)

$(0.046)^{* *}$

$-0.159$

$(0.064)^{*}$

0.029

(0.057)

0.022

(0.050)

$-0.015$

(0.035)

0.048

(0.047)

$-0.000$

(0.044)

\subsection{0}

(0.058)

0.060

(0.069)

0.016

$-0.023$

0.015

(0.058)

(0.049)

(0.083)

Mother studied same discipline

Age

0.003

(0.008)

$-0.033$

(0.079)

$-0.062$

$(0.067)$

0.024

(0.111)

$-0.000$

(0.013)

0.008

(0.009)

0.004

(0.007)

Female

$-0.214$

$(0.032)^{* *}$

$-0.234$

$(0.040)^{* *}$

$-0.210$

$-0.176$

$(0.034)^{* *}$

Gap betw. exp. \& nec. years of study

$-0.007$

(0.025)

$-0.068$

$(0.024)^{* *}$

$-0.043$

$-0.039$

$-0.009$

(0.037)

$-0.023$

(0.055)

(0.037)

$(0.017)^{*}$

Info from univ. publications $(0 / 1)$

0.036

(0.056)

0.096

(0.083)

Info from special reports $(0 / 1)$

$-0.017$

(0.047)

0.043

(0.076)

0.006

(0.063)

0.041

(0.047)

$-0.212$

$-0.080$

$(0.095)^{*}$

(0.052)

$-0.057$

(0.051)

0.025

(0.083)

Info from daily/weekly press $(0 / 1)$

0.078

$-0.025$

$(0.030)^{\text {** }}$

(0.039)

0.003

0.046

(0.036)

(0.031)

Info from pers. communication $(0 / 1)$

0.033

(0.029)

0.046

(0.039)

0.093

$(0.041)^{*}$

0.022

(0.031)

$-0.050$

(0.093)

$-0.005$

(0.107)

$-0.000$

(0.078)

$-0.095$

(0.148)

0.015

(0.052)

0.341

(0.196)

0.010

0.160

$-0.029$

$-0.261$

(0.050)

(0.110)

(0.111)

$(0.092)^{* *}$

$-0.027$ 


$\begin{array}{lcccc} & (0.040) & (0.070)^{*} & (0.053) & (0.053) \\ \text { Reason select school: assigned (0/1) } & -0.151 & -0.021 & -0.057 & -0.114 \\ & (0.057)^{* *} & (0.156) & (0.118) & (0.071) \\ \text { Interest in subject (0/1) } & -0.016 & 0.088 & -0.062 & -0.031 \\ & (0.037) & (0.070) & (0.048) & (0.054) \\ \text { Enrolled in 1998 } & -0.041 & -0.106 & 0.047 & -0.030 \\ \text { Enrolled before 1998 } & (0.048) & (0.082) & (0.046) & (0.047) \\ & -0.089 & -0.012 & -0.012 & 0.027 \\ \text { Relative performance (0-6) } & (0.059) & (0.051) & (0.053) & (0.125) \\ & 0.066 & 0.105 & 0.068 & 0.026 \\ \text { Hours worked while at school } & (0.020)^{* *} & (0.023)^{* *} & (0.027)^{*} & (0.019) \\ & 0.001 & 0.002 & 0.002 & 0.002 \\ \text { Smoker (0/1) } & (0.002) & (0.003) & (0.003) & (0.003) \\ & 0.038 & -0.091 & -0.045 & -0.052 \\ \text { Constant } & (0.029) & (0.050) & (0.053) & (0.038) \\ & 8.510 & 7.761 & 7.975 & 8.842 \\ \text { Number of observations } & (0.183)^{* *} & (0.316)^{* *} & (0.337)^{* *} & (0.198)^{* *} \\ \text { Adjusted R-squared } & 981 & 520 & 826 & 496 \\ & 0.13 & 0.20 & 0.18 & 0.16\end{array}$

Robust standard errors in parentheses

$*$ significant at $5 \%$; ** significant at $1 \%$ 
Table 6: Expected college-high school differential: the role of institutions

\begin{tabular}{|c|c|c|}
\hline & \multicolumn{2}{|c|}{$\begin{array}{l}\text { Expected college-high school wage } \\
\text { differential }\end{array}$} \\
\hline & $\begin{array}{l}\text { At entry into } \\
\text { labor market }\end{array}$ & $\begin{array}{c}\text { After } 10 \text { years of } \\
\text { experience }\end{array}$ \\
\hline Female & $\begin{array}{l}0.378 * * \\
(0.071)\end{array}$ & $\begin{array}{l}0.404^{*} \\
(0.198)\end{array}$ \\
\hline Growth rate of labor productivity & $\begin{array}{l}1.157 * * \\
(0.333)\end{array}$ & $\begin{array}{l}2.034 * * \\
(0.288)\end{array}$ \\
\hline Kaitz index for minimum wage & $\begin{array}{l}-1.816^{* *} \\
(0.540)\end{array}$ & $\begin{array}{l}-2.709 * * \\
(0.866)\end{array}$ \\
\hline Union density & $\begin{array}{l}-1.465 * * \\
(0.259)\end{array}$ & $\begin{array}{l}-1.421 * * \\
(0.334)\end{array}$ \\
\hline Share of public employment & $\begin{array}{l}0.177 * * \\
(0.049)\end{array}$ & $\begin{array}{l}0.233 * * \\
(0.0545)\end{array}$ \\
\hline Stratified education system $(0,1)$ & $\begin{array}{l}1.240 * * \\
(0.262)\end{array}$ & $\begin{array}{l}1.789 * * \\
(0.315)\end{array}$ \\
\hline Formal admission procedure $(0,1)$ & $\begin{array}{r}0.003 \\
(0.207)\end{array}$ & $\begin{array}{r}0.134 \\
(0.163)\end{array}$ \\
\hline $\begin{array}{l}\text { Strictness of admission procedure } \\
\text { relative to national level }(0,2)\end{array}$ & $\begin{array}{r}0.059 \\
(0.097)\end{array}$ & $\begin{array}{l}0.474 * * \\
(0.125)\end{array}$ \\
\hline Private university $(0,1)$ & $\begin{array}{r}0.097 \\
(0.095)\end{array}$ & $\begin{array}{r}-0.060 \\
(0.111)\end{array}$ \\
\hline $\begin{array}{l}\text { Prestige in education relative to national } \\
\text { level }(0,2)\end{array}$ & $\begin{array}{l}-0.093 \\
(0.066)\end{array}$ & $\begin{array}{r}-0.259 \\
(0.147)\end{array}$ \\
\hline $\begin{array}{l}\text { Prestige in research relative to national } \\
\text { level }(0,2)\end{array}$ & $\begin{array}{r}0.001 \\
(0.094)\end{array}$ & $\begin{array}{r}0.129 \\
(0.275)\end{array}$ \\
\hline $\begin{array}{l}\text { R Squared } \\
\text { Number of observations }\end{array}$ & $\begin{array}{l}0.65 \\
64\end{array}$ & $\begin{array}{l}0.76 \\
64\end{array}$ \\
\hline
\end{tabular}

Note: Weighted least squares results, data points are means by gender and university.

Dependent variables: Expected college wage gain at entry in the labor market and after ten years of experience.

* significant at the $10 \%$ level; ** significant at the $5 \%$ level. 
Table 7: The estimated coefficient of the expected entry college wage, in an expected college earnings growth regressions

\begin{tabular}{lc}
\hline All countries & $-0.085^{* *}$ \\
& $(0.015)$ \\
Germany & -0.046 \\
& $(0.023)$ \\
Italy & $-0.153^{*}$ \\
& $(0.071)$ \\
Portugal & $-0.236^{* *}$ \\
& $(0.048)$ \\
Switzerland & -0.073 \\
& $(0.041)$
\end{tabular}

Note: Robust standard errors in parentheses. Additional controls are the explanatory variables used in Tables 1-4.

* significant at the $10 \%$ level; ** significant at the $5 \%$ level. 


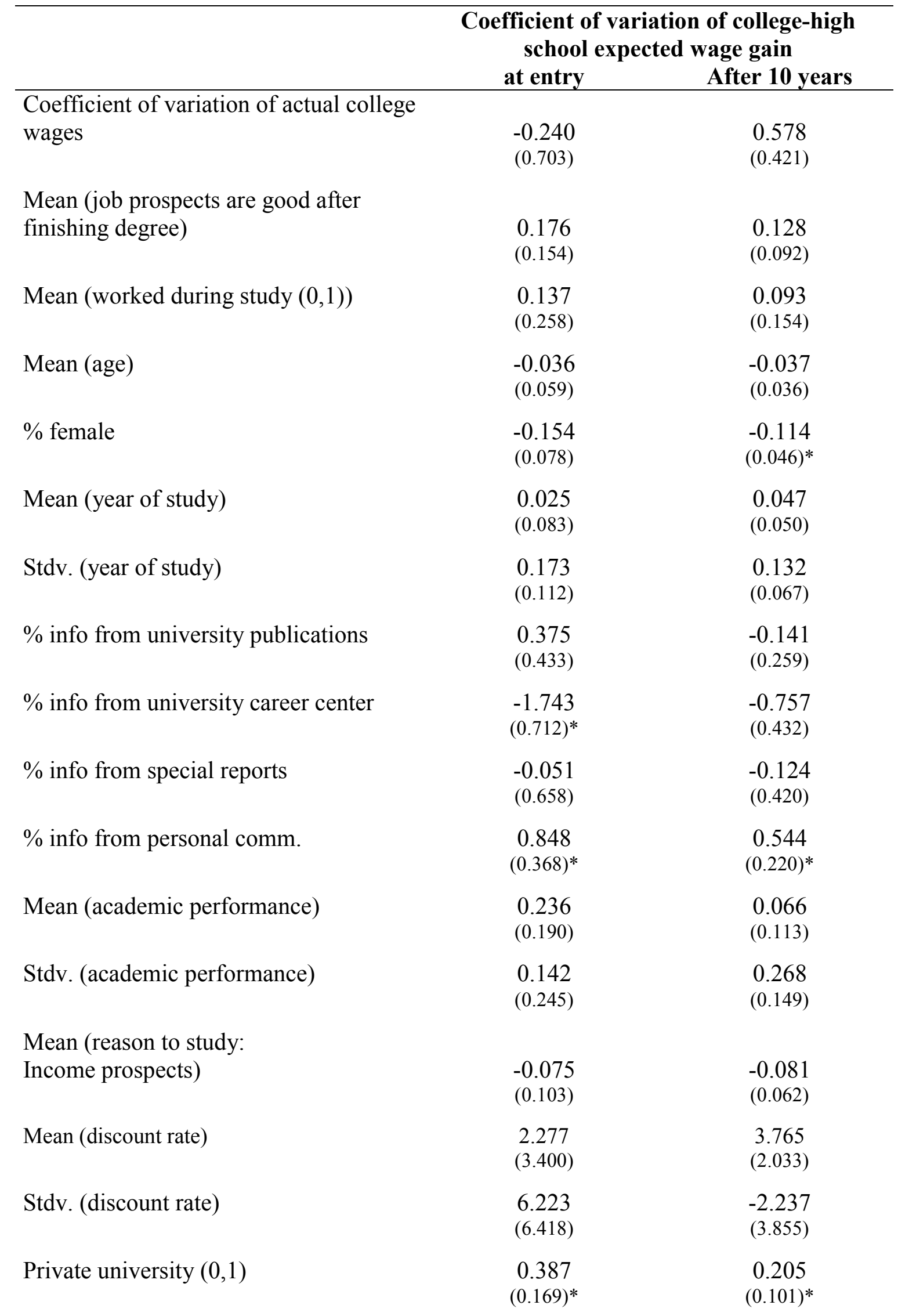


Strict admission criteria $(0,2)$

Observations

Mean of LHS (coeff. of var.)

Prob. value for F-test (field dummies)

Prob. value for F-test (country

dummies)

Adjusted R-squared
$-0.247$

$(0.116)^{*}$

141

0.90

0.00

0.03

0.29
$-0.146$

$(0.069)^{*}$

139

0.78

0.01

0.04

0.34

Data points are means (or standard deviations) by university and faculty.

Standard errors in parentheses, country and field dummies not shown in the table, F-tests show their significance, weighted least squares.

$*$ significant at $5 \% ; * *$ significant at $1 \%$ 
Figure 1 . The college wage gain by gender. At labor market entry and 10 years after entry.
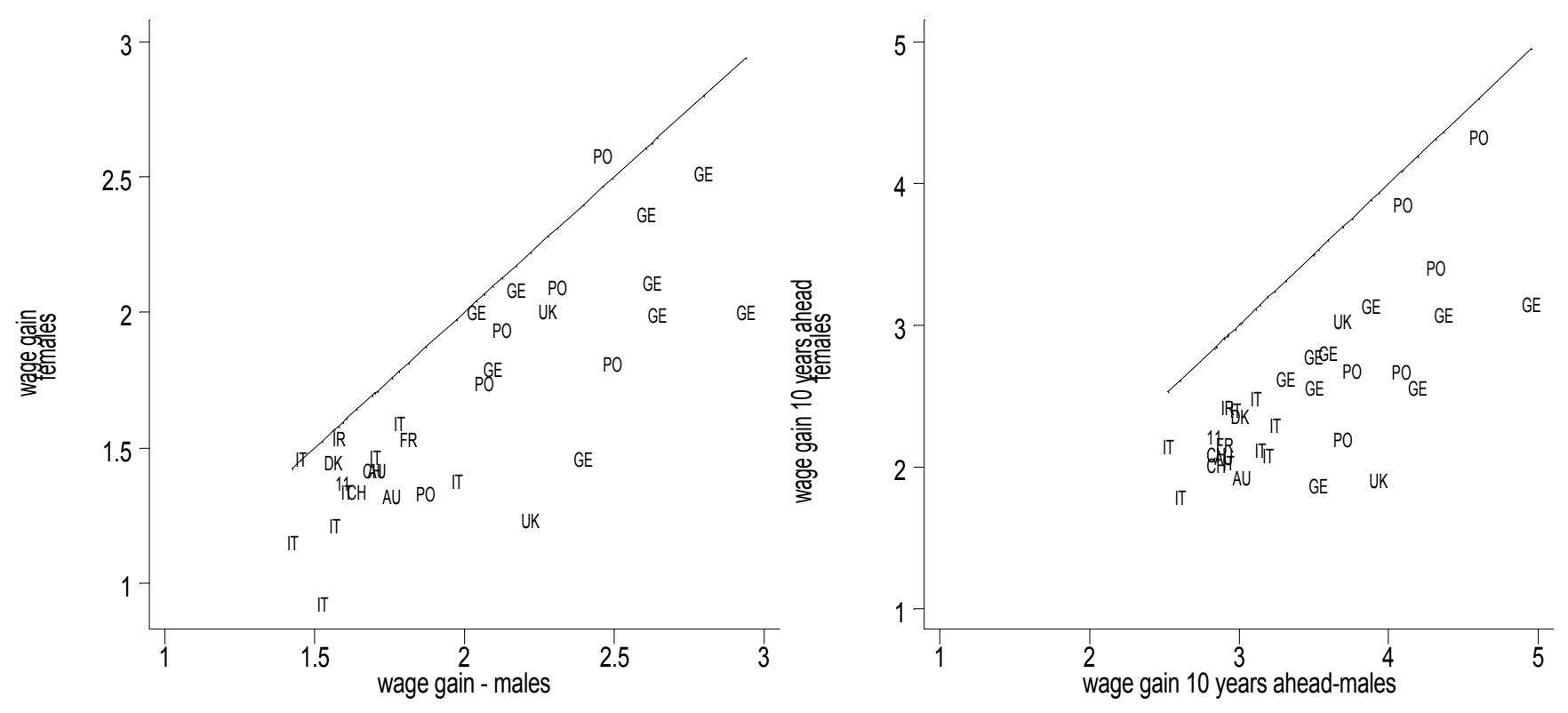
Figure 2. The college wage gain at entry and after ten years. By gender.
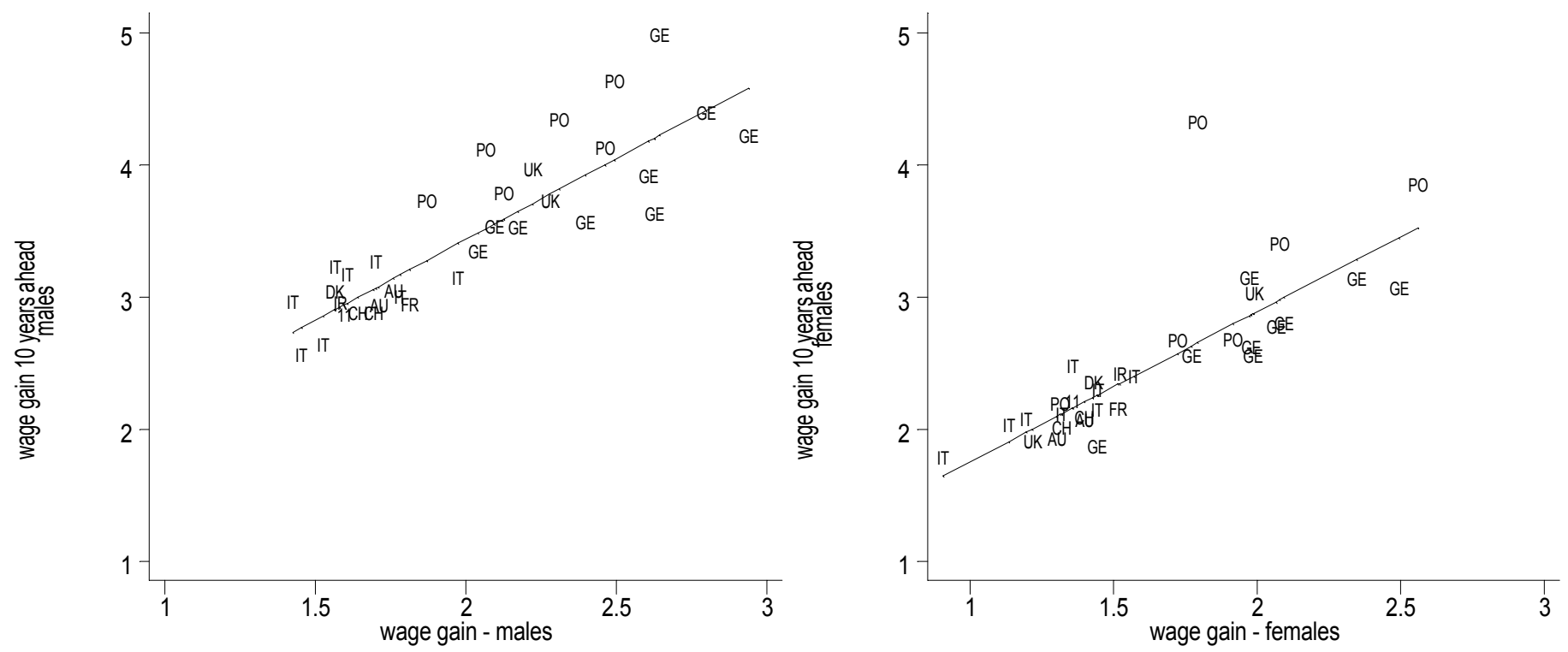
Figure 3. Expected and actual college gains at labor market entry (College vs. High-school, Males)

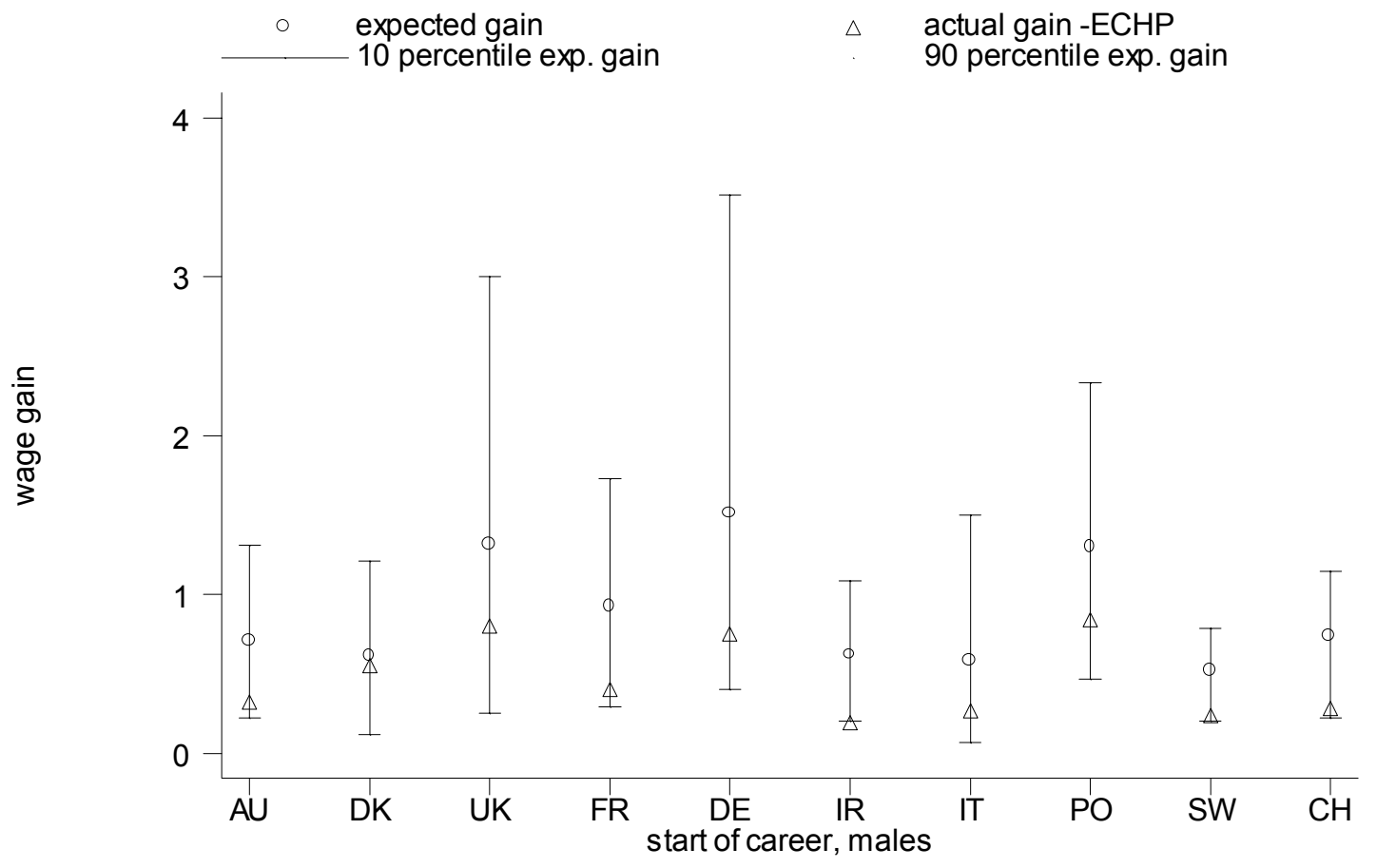


Figure 4. Expected and actual college gains at labor market entry (College vs. High-school, Females)

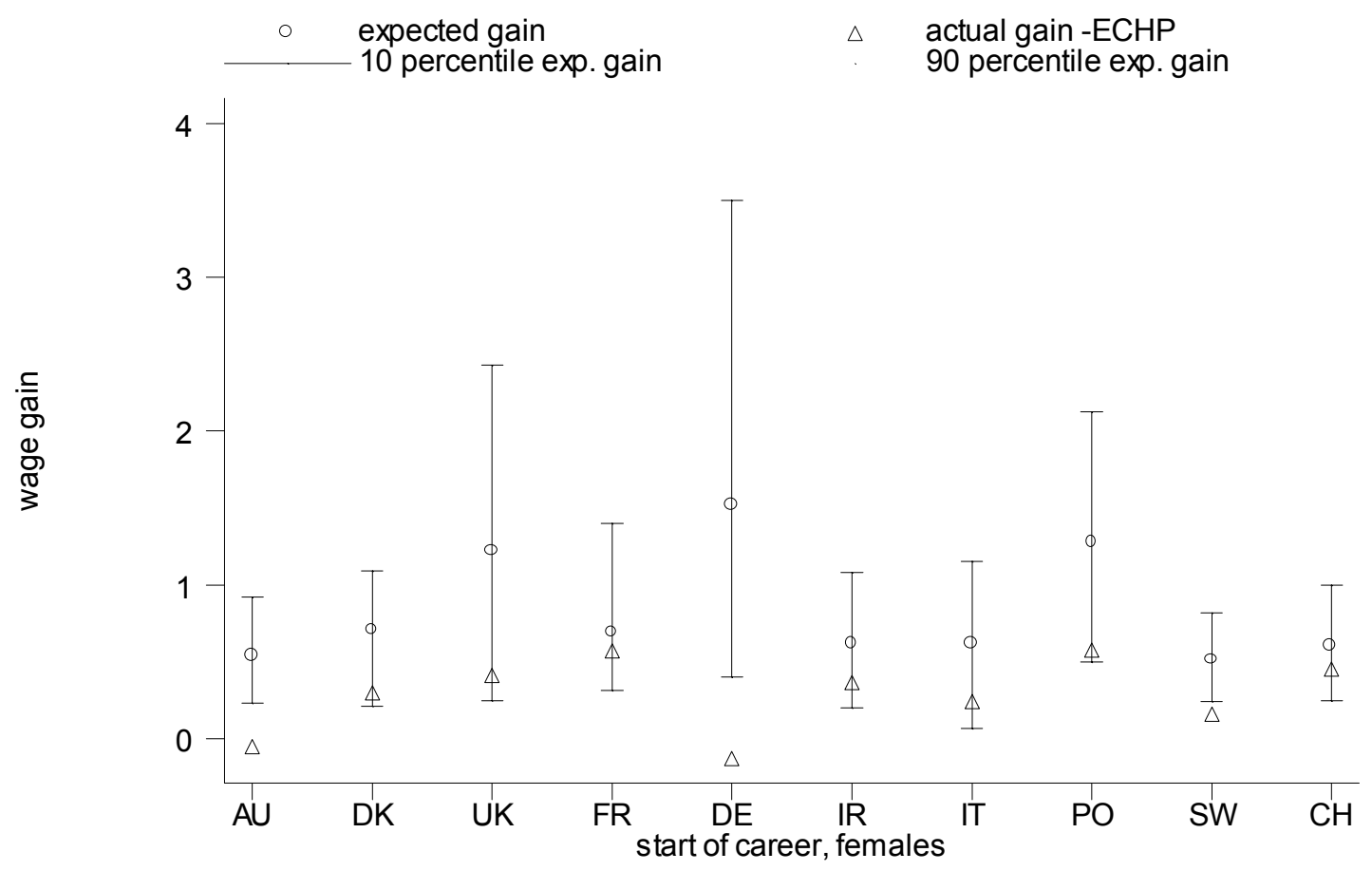


Table A1: Frequency distribution of valid questionnaires by country, university and faculty

\begin{tabular}{|c|c|c|c|c|c|c|}
\hline & University & Country & Faculty & Frequency & Percent & Missing \\
\hline (1) & (2) & (3) & (4) & (5) & (6) & (7) \\
\hline 1 & University of Linz & $\mathrm{AU}$ & $\begin{array}{l}\text { Ec,En,Sc } \\
\mathrm{M} \& \mathrm{~B}\end{array}$ & 174 & 3.11 & \multirow[t]{2}{*}{0.208} \\
\hline 2 & University of Vienna & $\mathrm{AU}$ & $\mathrm{M} \& \mathrm{~B}$ & 107 & 1.92 & \\
\hline 3 & Aarhus School of Business & DK & $\mathrm{M} \& \mathrm{~B}$ & 284 & 5.08 & 0.072 \\
\hline 4 & Essex University & UK & $\mathrm{Ec}$ & 40 & 0.72 & \multirow[t]{2}{*}{0.199} \\
\hline 5 & Stirling University & UK & $\mathrm{Ec}$ & 137 & 2.45 & \\
\hline 6 & $\begin{array}{l}\text { Université de Paris II } \\
\text { 'Pantheon-Assas' }\end{array}$ & FR & $\mathrm{Ec}$ & 240 & 4.29 & 0.262 \\
\hline 7 & Humboldt University of Berlin & $\mathrm{DE}$ & Ec, B\&M & 205 & 3.67 & \multirow{9}{*}{0.196} \\
\hline 8 & $\begin{array}{c}\text { Rheinische Friedrich-Wilhelms } \\
\text { University of Bonn }\end{array}$ & $\mathrm{DE}$ & $\mathrm{Sc}$ & 100 & 1.79 & \\
\hline 9 & Tech University Dresden & $\mathrm{DE}$ & Ec & 56 & 1 & \\
\hline 10 & $\begin{array}{c}\text { Friedrich-Alexander University of } \\
\text { Erlangen-Nuernberg }\end{array}$ & $\mathrm{DE}$ & $\mathrm{SSc}$ & 502 & 8.98 & \\
\hline 11 & $\begin{array}{l}\text { Ernst-Moritz-Arndt University of } \\
\text { Greifswald }\end{array}$ & $\mathrm{DE}$ & $\mathrm{Ec}, \mathrm{B} \& \mathrm{M}$ & 31 & 0.55 & \\
\hline 12 & Hannover University & $\mathrm{DE}$ & Ec, Law & 40 & 0.72 & \\
\hline 13 & $\begin{array}{l}\text { Friedrich Schiller University of } \\
\text { Jena }\end{array}$ & $\mathrm{DE}$ & $\mathrm{Ec}$ & 251 & 4.49 & \\
\hline 14 & University of Mannheim & $\mathrm{DE}$ & $\mathrm{SSc}$ & 28 & 0.5 & \\
\hline 15 & University of Regensburg & $\mathrm{DE}$ & $\mathrm{Ec}, \mathrm{M} \& \mathrm{~B}$ & 110 & 1.97 & \\
\hline 16 & University College Dublin & IRL & $\mathrm{Ec}, \mathrm{M} \& \mathrm{~B}$ & 447 & 8 & 0.219 \\
\hline 17 & Università di Reggio Calabria & IT & Ec & 91 & 1.63 & \multirow{8}{*}{0.066} \\
\hline 18 & Università dell'Insubria: Como & IT & Law & 5 & 0.09 & \\
\hline 19 & Università Statale di Milano & IT & $\mathrm{SSc}$ & 52 & 0.93 & \\
\hline 20 & Università Cattolica di Milano & IT & $\mathrm{Ec}$ & 185 & 3.31 & \\
\hline 21 & Milano Politecnico & IT & En & 47 & 0.84 & \\
\hline 22 & Università di Napoli & IT & $\mathrm{Ec}$ & 123 & 2.2 & \\
\hline 23 & Università di Padova & IT & $\mathrm{Ec}$ & 48 & 0.86 & \\
\hline 24 & Università Cattolica di Piacenza & IT & $\mathrm{Ec}$ & 70 & 1.25 & \\
\hline 25 & Technical University of Lisbon & PTG & En & 181 & 3.2 & \multirow{6}{*}{0.196} \\
\hline 26 & New University of Lisbon & PTG & Ec. Law & 630 & 11.2 & \\
\hline 27 & Politechnical Institute of Lisbon & PTG & $\mathrm{M} \& \mathrm{~B}$ & 36 & 0.6 & \\
\hline 28 & Administration Institute (Lisbon) & PTG & $M \& B$ & 41 & 0.7 & \\
\hline 29 & Azores University & PTG & Ec & 162 & 2.8 & \\
\hline 30 & Lusiada University (Lisbon) & PTG & $\mathrm{Ec}$ & 41 & 0.7 & \\
\hline 31 & Stockholm University & SW & $\mathrm{Ec}$ & 314 & 5.62 & 0.158 \\
\hline 32 & Bern University & $\mathrm{CH}$ & $\mathrm{Ec}$ & 455 & 8.14 & \multirow[t]{2}{*}{0.212} \\
\hline 33 & Zurich University & $\mathrm{CH}$ & Ec & 312 & 5.58 & \\
\hline & Total & & & 5589 & 100 & \\
\hline
\end{tabular}

Note: $\quad$ Data from Finland (Helsinki) and Greece (Athens) were not considered in the empirical analysis.

$\mathrm{Ec}=$ economics; $\mathrm{M} \& \mathrm{~B}=$ management $\&$ business; En=engineering; $\mathrm{SSc}=$ social science $\&$ liberal arts; $\mathrm{Sc}=$ science; Law=law; Med=medicine. 
Table A2: Descriptive statistics and main characteristics of the respondents

\begin{tabular}{|c|c|c|}
\hline \multirow[t]{2}{*}{ Variable } & \multicolumn{2}{|c|}{ Mean values } \\
\hline & male & Female \\
\hline \multicolumn{3}{|l|}{ Respondent characteristics } \\
\hline - $\quad$ age $(\#)$ & 21.25 & 20.90 \\
\hline - $\quad$ smokers (currently) & 0.77 & 0.78 \\
\hline - work during college & 0.66 & 0.67 \\
\hline \multicolumn{3}{|l|}{ Parents' education } \\
\hline \multicolumn{3}{|l|}{ Father } \\
\hline - no-degree & 0.13 & 0.16 \\
\hline - apprenticeship training & 0.22 & 0.23 \\
\hline - upper secondary diploma & 0.14 & 0.16 \\
\hline - university degree & 0.38 & 0.31 \\
\hline \multicolumn{3}{|l|}{ Mother } \\
\hline - no-degree & 0.17 & 0.20 \\
\hline - apprenticeship training & 0.26 & 0.25 \\
\hline - upper secondary diploma & 0.20 & 0.20 \\
\hline - university degree & 0.23 & 0.23 \\
\hline \multicolumn{3}{|l|}{ Same education as parent } \\
\hline - $\quad$ same study as father & 0.12 & 0.10 \\
\hline - $\quad$ same study as mother & 0.05 & 0.06 \\
\hline \multicolumn{3}{|l|}{ Year of study } \\
\hline - $\quad$ year 1 & 0.51 & 0.48 \\
\hline - $\quad$ year 2 & 0.24 & 0.24 \\
\hline - year 3 & 0.11 & 0.12 \\
\hline - year 4 and over & 0.14 & 0.15 \\
\hline \multicolumn{3}{|l|}{ Field of study } \\
\hline $\begin{array}{l}\text { - economics, business \& } \\
\text { management }\end{array}$ & 0.69 & 0.63 \\
\hline - $\quad$ social science \& liberal arts & 0.07 & 0.15 \\
\hline - $\quad$ natural science \& engineering & 0.13 & 0.05 \\
\hline - law & 0.07 & 0.10 \\
\hline - other & 0.02 & 0.05 \\
\hline \multicolumn{3}{|l|}{ College performance } \\
\hline $\begin{array}{l}\text { relative performance } \\
(1=\operatorname{good} ; 6=\text { poor })(\#)\end{array}$ & 2.62 & 2.66 \\
\hline $\begin{array}{l}\text { - more than 'normal' years to } \\
\text { complete college (\% individ) }\end{array}$ & 0.68 & 0.74 \\
\hline Obs & 2514 & 2250 \\
\hline
\end{tabular}

note: continuous variables are marked with (\#), all other variables indicate relative proportion in the sample. 
Table A3: Country specific values of the regressors in Table 6.

\begin{tabular}{cccccc}
\hline Country & $\begin{array}{c}\text { Growth of } \\
\text { labor prod. }\end{array}$ & $\begin{array}{c}\text { Stratified edu. } \\
\text { system }\end{array}$ & $\begin{array}{c}\text { Public } \\
\text { employment }\end{array}$ & Kaitz index & Union density \\
\hline & & & & & \\
\hline Austria & 0.0151 & 1 & 0.23 & 0.62 & 0.47 \\
Denmark & 0.0123 & 0 & 0.34 & 0.54 & 0.74 \\
France & 0.0143 & 0 & 0.28 & 0.50 & 0.09 \\
Germany & 0.0138 & 1 & 0.26 & 0.55 & 0.31 \\
Ireland & 0.0260 & 0 & 0.24 & 0.55 & 0.53 \\
Italy & 0.0215 & 0 & 0.25 & 0.71 & 0.26 \\
Portugal & 0.0279 & 0 & 0.23 & 0.45 & 0.45 \\
Sweden & 0.0080 & 0 & 0.37 & 0.52 & 0.86 \\
Switzerland & 0.0110 & 1 & 0.24 & 0.52 & 0.26 \\
\hline
\end{tabular}

Source: OECD databank; Brunello, Comi and Lucifora (2000). 


\section{Table A4: Questionnaire:}

Except for the Nordic countries, the questionnaire was held in the local language. Net wages were asked for countries, where net returns were available, gross wages else. Below the net-wage survey is shown - changes are in questions 10 and 11.

This is a survey about income prospects of students which is carried out in all European countries. We would kindly ask you to answer the following questions. It should not take you more than 10 minutes. Thank you very much for your cooperation.

1. What is your field of study?
(1) business studies, economics
(4) law
(2) social science and liberal arts
(5) medicine
(3) natural science, engineering
(6) other

2. What level of schooling did your parents achieve (final degree reached)?

\section{Father}

(1) no formal degree

(2) apprenticeship training

(3) high-school degree

(4) university degree

(5) don't know

\section{Mother}

(1) no formal degree

(2) apprenticeship training

(3) high-school degree

(4) university degree

(5) don't know

3. Do you study the same field as your father?

(1) father did not study

(2) yes

(3) no

4. Do you study the same field as your mother?

(1) mother did not study

(2) yes

(3) no

5. When did you start your university studies? In $19 \ldots .$.

6. How many years are formally required for a first degree? years

7. When do you expect to finish your studies with a first degree?
in the year
(1) 2000
(2) 2001
(3) 2002
(4) 2003
(5) 2004
(6) later: ......

8. Please mark your personal academic performance (relative to your colleagues') in the following scale. very good
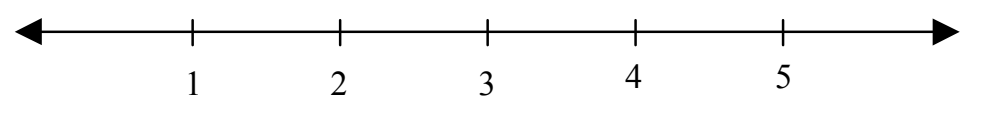

very poor 
9. Have you ever read/heard reports about income prospects of university graduates and where (multiple answers are possible)?
(1) in university publications
(4) in a special earnings prospects
study/survey
(2) in the university career center / job placement center
(5) personal communication (e.g. friends, relatives, colleagues ...)
(3) in the daily/weekly press
(6) never

10. What do you expect to earn right after finishing your degree (first degree possible at your university). State an approximate amount per month (net, i.e. after paying taxes)?

11. What would you have earned if you had started working right after finishing high-school? (again the approximate amount per month net after paying taxes)

12. Please tell us your expectations about wage growth:

a) Having finished my university degree, after 10 years on the job I will earn $\%$ more than in the first year.

b) Not having done a university degree (i.e. had I started right after high-school), after 10 years on the job I would earn ........\% more than in the first year.

13. How do you consider your chances of getting an appropriate job after graduating?
(1) very poor
(2) poor
(3) average
(4) good
(5) very good

14. Are these chances better or worse as compared to having a high-school education only? The prospects after finishing university are
(1) much worse
(2) worse
(3) same
(4) better
(5) much better

15. Do you hold a regular job during your studies?

(1) yes, hours a week

(2) no

16. How much do you spend per year of your study in directly university-related expenses (eg. tuition, books)?

17. How much do you spend per year of your study in housing/living expenses? 
18. What were the determinants for your choice of study? Please rank the following items between 1 (most important) and 6 (least important).

_ Proximity to my home town

_ Academic reputation/standard

_ Costs (e.g. housing, tuition...)
_ Income and job prospects

- Assignment

_ Interest in the subject

19. Imagine a situation, where you and some of your colleagues (A-F) will get a gift from an unknown person. You will get 1000 Euros today. Do you consider yourself better or worse off as compared to each of your colleagues? (Please give an answer to all situations below.)
A will get 1020 Euros in one year
(1) better off
I am
B will get 1040 Euros in one year
(1) better off
(2) worse off than A
C will get 1060 Euros in one year
(1) better off
(2) worse off than B
D will get 1080 Euros in one year
(1) better off
(2) worse off than $\mathrm{C}$
E will get 1100 Euros in one year
(1) better off
(2) worse off than D
F will get 1120 Euros in one year
(1) better off
(2) worse off than E

20. How old are you?

years

21. Gender

(1) male

(2) female

22. Do you smoke?

(1) yes

(2) no

23. Have you smoked at age $17 / 18$ ?
(1) yes
(2) no 